\title{
The Right to Silence and the Pendulum Swing: \\ Variations in Canadian and Scottish Criminal Law
}

\author{
Kathryn M. Campbell \\ Department of Criminology \\ University of Ottawa \\ Canada
}

The right to silence is afforded to suspects in criminal cases as part of a number constitutional protections contained within Canadian law through the Charter of Rights and Freedoms. It is closely linked to other such rights, including the right to counsel, the right against self-incrimination and the presumption of innocence. Moreover, in some cases, the denial of this right has resulted in convictions in error through false confessions and wrongful convictions. Decisions by the Supreme Court in Canada in recent times can be viewed as a slow encroachment onto individual Charter rights in favour of the needs of law enforcement. In Scotland, until recently, while afforded a right to silence suspects could still be questioned for up to six hours without a lawyer present. While other measures existed to protect an individual's right to a fair trial, such practices were out of step with the European Convention on Human Rights Article 6(1) right to a fair trial. In the decision in Cadder v HMA, greater protections to suspects were introduced regarding the right to silence and the right to counsel, and the Criminal Justice (Scotland) Act 2016 later consolidated the relevant law on this matter. The focus of this paper will be to examine how the right to silence in both Canadian and Scottish law has evolved through statute and case law and the implications of this for law enforcement practices, the protection of rights and the safety of convictions.

I. Introduction

II. Canada
A. Right to Silence
B. Confessions Rule
C. Right to Counsel
D. Police Interrogation

III. Scotland

A. Case Law
a. Salduz v Turkey [2008]
b. HMA v McLean [2009]
c. Cadder v HM Advocate [2010]

B. Legislative Change

C. Further Decisions

IV. Discussion and Conclusions 


\section{Introduction}

When individual suspects are detained by police and questioned on their involvement in alleged criminal activity, they are placed in a vulnerable position. In many instances, such persons are ignorant of what their rights are regarding what questions they should or should not answer and what protections may be afforded to them in this respect. At the same time, law enforcement has the task of attempting to solve crime through collecting evidence, finding a suspect and charging them. Given the vulnerable state of the individuals questioned by the police, in juxtaposition to the power of the state, criminal procedure has evolved to the point where principles have been established that are aimed at protecting the rights of persons in such situations. In spite of these rights-based protections, increasingly the higher courts have interpreted their reach and it will be argued that decisions that tend to favour an increase in individual rights protections are often followed by further decisions that favour limiting those rights. The objective of this paper is to explore this metaphorical pendulum swing in the right to silence in the common law jurisdictions of both Canada and Scotland. ${ }^{1}$

Principle among the provisions protecting persons questioned by the police is the right to silence. The utility of the right to silence cannot be overstated. When questioned by the police, a suspect or accused person or witness has no obligation to help the police in their duties by making self-incriminatory statements. While it may appear rather straightforward, research has indicated that individuals do not always understand the meaning of this right, which may result in them being denied its protections. ${ }^{2}$ Moreover, in its attempt to establish the right to silence as an individual human right guarantee ${ }^{3}$, the European Court of Human Rights, recognized it not as an absolute right, but as largely dependent upon the setting in which it is sought. In fact, in her book Quirk underlines how the decline of the right to silence in England has been accompanied by a normative expectation of co-operation, which could be interpreted as a movement towards greater crime control. ${ }^{4}$ Ultimately, police work demands a balance between effective law enforcement and effective defence rights, ${ }^{5}$ a balance that is difficult to achieve given the competing forces on each side of the equation.

Essentially, this right functions to protect persons during police interview (and charged persons at trial) from making self-incriminating statements to those in authority. While statute and case law in both jurisdictions have established frameworks for protecting the right to silence, difficulties surrounding the protection of this right often emerge at the

\footnotetext{
${ }^{1}$ An earlier version of this paper was presented at the Gordon Seminar on Criminal Law, School of Law, University of Glasgow 2015. I would like to thank James McLean, Lewis Kennedy, Michael Crystal, Tara Santini, Fiona Leverick and Clive Walker for very helpful comments on early drafts.

${ }^{2}$ Joseph Eastwood, Brent Snook \& Sarah Chalk, "Comprehending Canadian police cautions: Are the Rights to Silence and Legal Counsel Understandable?" (2010) 28 Behav Sci \& L 366; Krista Davis, Lindsay Fitzsimmons \& Timothy Moore, "Improving the Comprehensibility of a Canadian Police Caution on the Right to Silence" (2011) 26:2 J Police \&Crim Psych 87.

${ }^{3}$ Mark Berger, "Self-incrimination and the European Court of Human Rights: Procedural issues in the Enforcement of the Right to Silence" (2007) 5 EHRLR 514 at 515.

${ }^{4}$ Hannah Quirk, The Rise and Fall of the Right to Silence (Routledge: London, 2016).

${ }^{5}$ Fenella Billing, The Right to Silence in Transnational Criminal Proceedings: Comparative Law Perspectives (Springer International Publishing: Switzerland, 2016) at 3.
} 
first point of contact with law enforcement officials. It may be argued that it is at this juncture that the right to silence serves different functions. For the innocent person, possibly unfamiliar with the extent of their rights in this context, waiving the right to silence in a sincere attempt to help in the investigation may inadvertently supply police with further evidence against them. Similarly, for the guilty the right to silence may act as a shield that forces law enforcement and prosecutors to effectively make the case against them; it is not the suspect's responsibility to facilitate a conviction, nor should it be. However, the guilt or innocence of a suspect per se, from a rights perspective, matters little. The underlying issue is that this protection serves as a means of somewhat leveling the playing field where one of the players is at a distinct disadvantage.

In Canada, the right to silence is closely linked to the right to counsel and the right against self-incrimination, as well as the overriding presumption of innocence. In fact, these rights are so closely connected that it is difficult to ascertain where one begins and the other ends; absent the right to counsel, the right to silence is at times ignored and the right to silence in and of itself enhances the right against self-incrimination. Similarly, the presumption of innocence, on which much of criminal procedure is based, underlies all of these protections. In Canadian law the principle of fundamental justice with respect to the notion of fairness in the administration of justice is found in the Canadian Charter of Rights and Freedoms ${ }^{6}$ (Charter) under section 7 and subsection 10 (b). Section 7 states: "Everyone has the right to life, liberty and security of the person and the right not to be deprived thereof except in accordance with the principles of fundamental justice." However, this section has been interpreted to be far more expansive than encompassing simply procedural rights, and includes, inter alia, protections around the right to silence. Further, subsection 10 (b) states that: "Everyone has the right on arrest or detention (b) to retain and instruct counsel without delay and to be informed of that right."

In Scotland similar protections are found in the European Convention on Human Rights $^{7}$ (ECHR) subsection 6 (1) Right to a fair trial: " 1 . In the determination of his civil rights and obligations or of any criminal charge against him, everyone is entitled to a fair and public hearing within a reasonable time by an independent and impartial tribunal established by law." Moreover, these protections are further reinforced by the right to counsel in subsection 6 (3) (c) whereby: "Everyone charged with a criminal offence has the following minimum rights: ... (c) to defend himself in person or through legal assistance of his own choosing or, if he has not sufficient means to pay for legal assistance, to be given it free when the interests of justice so require." The Criminal Justice (Scotland) Act $2016^{8}$ outlines police powers for detaining and questioning individuals suspected of criminal activity. Provision for legal assistance during detention, however, only came about due to case law in 2009 and changes in this regard will be discussed below. Further protections of

\footnotetext{
${ }^{6}$ Canadian Charter of Rights and Freedoms, Part 1 of the Constitution Act, 1982, being Schedule B to the Canada Act, 1982 (UK), 1982, c 11, online: 〈http://canlii.ca/t/ldsx > Charter).

${ }^{7}$ European Convention on Human Rights, as amended by Protocols Nos 11 and 14 supplemented by

Protocols Nos 1, 4, 6, 7, 12, 13 and 16, Rome 4.XI.1950, online:

https://www.coe.int/en/web/conventions/full-list/-/conventions/treaty/005r (ECHR).

${ }^{8}$ Criminal Justice (Scotland) Act, 2016, 2016 asp 1, online:

http://www.bailii.org/scot/legis/num_act/2016/asp_20161_en_1.html, at s 3 (e) (i-ii).
} 
these rights in Scotland can be found in the Human Rights Act, 1998, ${ }^{9}$ where section 6 repeats the protections of ECHR and the Scotland Act. ${ }^{10}$

In an adversarial system the enshrinement of such rights through statute and the common law provides further protection to persons when evidence collected in the early stages of an investigation is used against them at trial. A brief examination of case law will demonstrate that right-to-silence protections in both Canada and Scotland have recently gone through a number of variations. The first half of this paper will present an overview of developments in criminal law protections ${ }^{11}$ in the Canadian context including case law regarding the right to silence and the right to counsel. What becomes evident is that interpretations of these rights under section 7 of the Charter have resulted in an increasingly narrow application. How these rights are implemented in practice will also be discussed, as well as the controversies regarding the admission of evidence via contentious police interrogation methods. The second half of the paper will examine the shifts in Scottish criminal law in recent years that have resulted as both domestic courts and the European Court of Human Rights have interpreted the right to counsel under subsection 6 (3) (c), as well as through statutory changes. While it has become apparent that the courts in both jurisdictions have now established that protecting the right to silence and the right to counsel is an essential part of an overall greater recognition of human rights, at the same time significant erosions to those protections are also evident.

\section{Canada}

Section 7 and subsection 10 (b) of the Charter offer protections to the right to silence and the right to counsel and include both procedural and substantive aspects. ${ }^{12}$ In particular section 7 has been interpreted as conveying the right to silence both at the police investigative stage and also at trial. ${ }^{13}$ Furthermore, so-called legal rights under the Charter comprise subsections 7-14 and while not specifically defined as such, include “...the rights of persons within the system of criminal justice, limiting the powers of the state with respect to investigation, search, seizure, arrest, detention, trial and punishment". ${ }^{14}$ Amongst these legal rights, the right to silence essentially provides protection to individuals from the dominant power of the state.

\section{A. Right to Silence}

Given that the Canadian Charter was only enacted in 1982, the first case that examined this right to silence, in particular with respect to confession evidence was $R v$

${ }^{9}$ The Human Rights Act, 1998 c 42, online: http://www.bailii.org/uk/legis/num_act/1998/ukpga_19980042_en_1.html.

${ }^{10}$ The Scotland Act, 1998 c 46, online: http://www.bailii.org/uk/legis/num_act/1998/ukpga_19980046_en_1.html.

${ }^{11}$ The phrase "criminal law protections" refers to rights based protections afforded persons when questioned by the police. These terms, and the term "legal rights" will be used interchangeably.

${ }^{12}$ See eg, Re BC Motor Vehicle Act, 1985 CanLII 81 (SCC), [1985] 2 SCR 486, online: 〈http://canlii.ca/t/dln〉 at 499 .

${ }^{13}$ David Paciocco \& Lee Stuesser, The Law of Evidence, 7th ed (Toronto: Irwin Law, 2015).

${ }^{14}$ Peter Hogg, Constitutional Law of Canada, 5th ed. (Toronto: Thomson Reuters, 2007) 1028. 
Hebert. ${ }^{15}$ While this case considered the right of a detained person to silence under section 7 within the context of the confessions rule, it also considered the privilege against selfincrimination, the philosophy of the Charter and the purpose of the right in question. ${ }^{16}$ Here a robbery suspect made a number of incriminating statements to an undercover police officer in his holding cell, despite having told the police he did not want to make a statement to them. The Supreme Court of Canada later held that not only had Hebert's rights been violated by improper police questioning but also that the right to silence is the most important right to be advised of, which in effect allows the suspect the right to choose to speak to authorities, or not. ${ }^{17}$ The Court outlined the limits to the right to silence and they include that this right only applies after detention (although not to suspects targeted in undercover operations), and that the police may question people in the absence of counsel (after counsel has been retained). Further, the right does not extend to voluntary statements made to a cellmate, and it is not violated even when undercover police observe a suspect, but do not "elicit information in violation of the suspect's choice to remain silent." 18

While this decision only loosely defined the parameters of the right to silence, there continues to be little consensus within the legal community about the extent of its role in affording protection to criminal suspects. ${ }^{19}$ The ruling in Hebert was unanimous that section 7 included the right to silence, however, there was less clarity around the contours of that right, in effect reflecting what has been called the "Canadian ambivalence towards confessions." ${ }^{20}$ Being informed of the right to silence creates an assumption that such a right will offer protection against self-incrimination, however, it would seem that this is not always the case.

Another decision by the Supreme Court indicates that such rights are being gradually eroded. In $R v$ Singh $^{21}$ the Supreme Court attempted to further clarify the right to silence under section 7. It also examined the intersection between the right to silence (from Hebert) and the common law confessions rule as found in $R v$ Oickle $^{22}$ (to be discussed infra). Having been accused of second-degree murder, Singh made a number of incriminating admissions during questioning in spite of the fact that he had repeatedly attempted to end the interview. The issue before the Supreme Court was the admissibility of the statements made to the police on the grounds that they were involuntary and infringed

\footnotetext{
${ }^{15} R v$ Hebert, 1990 CanLII 118 (SCC), [1990] 2 SCR 151, online: <http://canlii.ca/t/1fst9> [Hebert]. While this case considered the right of a detained person to silence under $\mathrm{s} 7$ within the context of the confessions rule, it also considered the privilege against self-incrimination, the philosophy of the Charter and the purpose of the right in question (at para 20).

${ }^{16}$ Ibid at 15.

${ }^{17} \mathrm{Ibid}$ at $52,80$.

${ }^{18}$ Ronald Delisle \& Don Stuart, Evidence: Principles and Problems, 7th ed (Toronto, Carswell Legal Publications, 2004) at 382.

${ }^{19}$ See eg, Richard Litkowski, "Silencing the right to remain silent" (2008) 29:1 Ontario Criminal Lawyers' Association Newsletter at 1.

${ }^{20}$ Guy Cournoyer, "Saying 'no' to interrogation: The Quebec Court of Appeal asserts a meaningful right to silence" (2001) 5th CR at 2.

${ }^{21} R v$ Singh, 2007 SCC 48 (CanLII), [2007] 3 SCR 405, online: 〈http://canlii.ca/t/1tf56> [Singh].

${ }^{22} R$ v Oickle, 2000 SCC 38 (CanLII), [2000] 2 SCR 3, online: <http://canlii.ca/t/525h> [Oickle].
} 
his Charter right to silence. ${ }^{23}$ In dismissing Singh's appeal, the Court was significantly divided on the intersection of the confessions rule regarding voluntariness and the right to silence. The majority found:

...voluntariness, as it is understood today, requires that the court scrutinize whether the accused was denied his or her right to silence...In other words, if the Crown proves voluntariness beyond a reasonable doubt, there can be no finding of a Charter violation of the right to silence in respect of the same statement. ${ }^{24}$

The Court further argued that the confessions rule enhances or supplements the section 7 right to silence - rather than merely subsuming it. ${ }^{25}$ Questions of voluntariness are closely linked to whether or not an accused person was denied his or her right to silence and both affect the admissibility of confession evidence.

Overall the finding in Singh could open the door to excessive police interrogation practices insofar as they permit the suspect to choose to remain silent and are not so extreme as to violate the operating mind principle. ${ }^{26}$ In other words, persistent police practices are permissible in order to elicit admissions or confessions from the accused, as long as he/she is made aware of his/her right to silence and is capable of understanding the proceedings. However, the dissent in Singh found that his statements to the police did in fact violate his right to silence. Writing for the minority, Fish J stated that " ... a confession that meets these common law standards does not invariably represent a 'free and meaningful choice' for the purposes of the Charter". ${ }^{27}$ Thus, even if a confession could be considered voluntary under the confessions rule, at the same time it could have been obtained through state action that infringed section 7 of the Charter. ${ }^{28}$ The dissenting opinion appears to reflect a greater concern with the abuse of police powers over individual rights, while at the same time recognizing that the police have a particular responsibility to investigate crime and interrogate suspects. While the majority decision in Singh affirms that the voluntariness of statements is closely tied to Charter rights, it has also been argued that it represents a blow to the right to silence. ${ }^{29}$ Despite the fact that Mr. Singh asserted his right to silence 18 times, the ultimate question before the Court was whether or not he exercised free will in choosing to make a statement; ${ }^{30}$ the Court decided he had.

\section{B. Confessions Rule}

Closely related to the right to silence is the confessions rule, established by the Supreme Court in Oickle. In this case Oickle admitted to setting a fire, after much questioning by the police. At their urging, the defendant agreed to a re-enactment of a number of other fires, was subsequently charged and convicted of arson. While the

${ }^{23}$ Renée Weitzman \& Kathryn Campbell, "The Admissibility of Confessions: A Review of Hebert, Oickle, Singh and Sinclair" (Nat Jud Inst - Inst nat de la magistrature, Quebec, 2012) at 8 [Weitzman \& Campbell].

${ }^{24}$ Singh, supra note 21 at 37.

${ }^{25}$ Ibid at 39.

${ }^{26}$ Weitzman \& Campbell, supra note 23 at 9.

${ }^{27}$ Singh, supra note 21 at 79.

${ }^{28}$ Weitzman \& Campbell, supra note 23 at 9.

${ }^{29}$ Ibid at 1.

${ }^{30}$ Singh, supra note 21 at 53. 
confessions were admitted at trial, they were excluded by the Nova Scotia Court of Appeal, but later restored by the Supreme Court. At that time, however, the Court restored the confessions rule, and acknowledged the need for vigilance around admitting questionable confessions given their role in contributing to wrongful convictions. What Oickle established was that for a confession made to a person in authority to be admissible, the Crown had to establish beyond a reasonable doubt that the defendant had not been overborne by inducements, oppressive circumstances, lack of an "operating mind" or police trickery ${ }^{31} \mathrm{~A}$ contextual analysis is thus required in deciding the admissibility of a confession at trial. First of all, a confession will be deemed inadmissible if it came about due to threats, violence, a promise of leniency or inducements. Secondly, a confession is inadmissible if it results from oppression, or a desire to escape an oppressive circumstance to the degree that it overcomes the suspect's will. The operating mind doctrine, the third aspect of the rule, requires that the defendant have the cognitive capacity to understand what they are saying and understand the evidence against them. The final aspect of the confessions rule addresses what is considered to be other or unfair police trickery ${ }^{32}$ - as a confession will be deemed inadmissible when actions to obtain that confession on the part of the police are so appalling that they "shock the community." 33

\section{Right to Counsel}

The most significant decision regarding the right to counsel appears to further infringe up the right to silence. In 2010, the Supreme Court of Canada handed down three companion cases, all dealing with interrelated issues regarding the right to counsel, the right to silence, and the confessions rule. They included $R v$ McCrimmon, ${ }^{34} R v$ Willier, ${ }^{35}$ and $R v$ Sinclair, ${ }^{36}$ with the latter being the most controversial of the three, given the strong dissent. In Sinclair, the accused was arrested for murder and spoke to counsel on two occasions. During police interviews that occurred over several hours Sinclair stated he had nothing to say, and although the police affirmed his right to silence they did not allow him to re-consult his lawyer. He later made incriminating statements to the police and to an undercover officer in his cell; he also participated in a re-enactment at the murder site. At trial, the judge ruled that the interview, statements to the police and the re-enactment were

\footnotetext{
${ }^{31}$ Weitzman \& Campbell, supra note 23 at 6.

${ }^{32}$ Ibid at 7.

${ }^{33}$ From Oickle: Rothman v The Queen, 1981 CanLII 23 (SCC), [1981] 1 SCR 640, online: $\langle$ http://canlii.ca/t/1mj17>.

${ }^{34} R$ v McCrimmon, 2010 SCC 36 (CanLII), [2010] 2 SCR 402, online: 〈http://canlii.ca/t/2cvjx $>$ [McCrimmon].

${ }^{35}$ In McCrimmon the accused was given the right to counsel upon arrest for assault; while he identified a specific lawyer as his choice, he was unable to reach him. He accepted the offer to speak to legal aid and after two hours confessed. At trial the statements were found to be voluntary and the Court of Appeal affirmed the judge's rulings. In $R v$ Willier, 2010 SCC 37 (CanLII), [2010] 2 SCR 429, online: 〈http://canlii.ca/t/2cvjv> following his arrest for murder, Willier spoke to duty counsel on two occasions when unable to speak to his lawyer of choice and confessed to police one hour later. In his case, the trial found for a Charter breach as police did not allow sufficient time for him to reach his counsel of choice. The Court of Appeal, however, reversed his decision and found no breach. At the Supreme Court all the justices agreed that Willier had been given "ample opportunity to exercise his rights but had failed to do so.

${ }^{36} R v$ Sinclair, 2010 SCC 35 (CanLII), [2010] 2 SCR 310, online: 〈http://canlii.ca/t/2cvjs >, [Sinclair].
} 
all admissible and that Sinclair's rights under subsection 10 (b) of the Charter had not been infringed.

While the British Columbia Court of Appeal affirmed this decision, the Supreme Court examined whether the right to counsel under the Charter (subsection 10 (b)) required that a lawyer be present at all times throughout an interrogation; the Court was ultimately split three ways on its understanding of this issue. ${ }^{37}$ While the purpose of this section of the Charter was to support a detained person's right to choose whether or not to cooperate with the police, based on advice from counsel, the issue boiled down to differences of opinion as to when the right to consult counsel ends, following an initial consultation. The majority position rendered by Justice Charron and then Chief Justice McLachlin represented a belief in the need for a narrow degree of protection for the accused, where the right to re-consult counsel was only permitted if there had been a change in circumstances. That would include a polygraph test or a lineup identification, a change in jeopardy facing the suspect (material change in the charge) or if there was reason to believe that the suspect who had waived their right to counsel may not have understood the advice given by the police about that right. ${ }^{38}$ The dissent, from Justices LeBel and Fish, conveyed a more expansive view, ${ }^{39}$ where the right to counsel was viewed as a continuing right, to be asserted at any point and consistent with the notion of jeopardy. For them, the right protects the accused from self-incrimination and also ensures the presumption of innocence. Absent these protections, the chances of a guilty plea increase, as well as the admission of incriminating statements, all hallmarks of a possible wrongful conviction. Ultimately, for the dissent the right to counsel should reach beyond a one-time consultation; the suspect has an inherent right not to be part of building a case against him or herself. ${ }^{40}$

Justice Binnie's dissent was more intermediate as he argued for allowing the detainee "reasonable access to legal advice from time to time in the course of a police interrogation." ${ }^{41}$ Sinclair's consultation with counsel over the phone constituted a total of 360 seconds of legal advice, which Binnie, J, argues was not "enough to exhaust his s.10 (b) guarantee." 42 Binnie's position reflects the belief that this and other cases (Singh, Oickle) have now lowered the bar so that:

...an individual (presumed innocent) may be detained and isolated for questioning by the police for at least five or six hours without reasonable recourse to a lawyer, during which time the officers can brush aside assertions of the right to silence or demands to be returned to his or her cell, in an endurance contest in which the police interrogators, taking turns with one another, hold all the important legal cards. ${ }^{43}$

Considered in combination with the above cases, Sinclair is representative of a slow encroachment into individual Charter rights and a shift in the Court's view on subsection

\footnotetext{
${ }^{37}$ Weitzman \& Campbell, supra note 23 at 10.

${ }^{38}$ Sinclair, supra note 36 at 36.

${ }^{39}$ Or "purposive" view, see Weitzman \& Campbell, supra note 23 at 10.

${ }^{40}$ Ibid at 10.

${ }^{41}$ Sinclair, supra note 36 at 105.

${ }^{42}$ Ibid at 83.

${ }^{43}$ Ibid at 98
} 
10 (b) rights, again in favour of the needs and interests of law enforcement. ${ }^{44}$ The overall decision of the Court in Sinclair underlines the tension between balancing societal interests in solving crime and protecting the public, with the rights of accused persons under the Charter. Despite several lengthy, protracted considerations by the highest court in Canada, the law with respect to the right to silence and to ascertaining the voluntariness of confessions remains in dispute.

In practice, what the decision in Sinclair means is that following an initial consultation ${ }^{45}$ with counsel, a suspect will only be permitted to re-consult counsel if there has been a material change in circumstance. This could include the introduction of new procedures or a change in jeopardy or if police are of the opinion that the first information was deficient. ${ }^{46}$ For police this translates into what amounts to almost unfettered access to questioning suspects following the first consultation. Suspects do not have the right to have counsel present for the duration of the police interview; in Canadian law the right to counsel at this stage in the process is one of pre-questioning consultation and not one of representation during a police interview. In fact, some defense counsel when consulted advise clients over the phone to "curl up in a fetal position and don't say anything." 47 Others, state, "in the past I would frequently advise clients to take my card, put it between their teeth and bite down on it if the police wanted to take a statement from them". "While such advice is somewhat tongue in cheek, it reflects the reality of what occurs in these situations. A suspect would need to be incredibly resilient to stand up to relentless questioning by police officers, in the intimidating environment of the interrogation room of a police station. While there are certainly protections through section 7 of the Charter against an abuse of process on the part of the police, the extent of the limits of permitted police questioning of detainees have as of yet to be clearly established by the courts.

Further case law since the Sinclair decision has refined some of the questions that decision left unanswered. ${ }^{49}$ In particular, some clarifications have occurred in terms of what a change in jeopardy requiring re-consultation with counsel means, ${ }^{50}$ what a lack of understanding of legal advice means, ${ }^{51}$ defining the limits of what facilitation of contact

\footnotetext{
44 Vanessa A. MacDonnell, "R v Sinclair: Balancing individual rights and societal interests outside of section 1 of the Charter' (2012) 38 Queen's L J 137.

${ }^{45}$ Consultations can occur over the phone as it is not required that the suspect meet with counsel in person.

${ }^{46}$ Sinclair, supra note 36 at 2.

${ }^{47}$ Michael Crystal, criminal defense counsel, personal communication, 1 May 2015.

${ }^{48}$ From Douglas Quan. “Acquitted woman's emotional statement to police was admissible in murder trial, appeal court rules" (8 Jun 2015), National Post, online: http://news.nationalpost.com/toronto/womansemotional-statement-to-police-was-admissible-in-murder-trial-appeal-court-rules.

${ }^{49}$ Joe Doyle \& Claire Hatcher, “The Sinclair Trilogy: 'What are Defence Counsel For?'” Online at: http://www.cba.org/cba/cle/PDF/CRIM12_Paper_Hatcher.pdf [Doyle \& Hatcher] 10-12.

${ }^{50} R v$ Gonzales, 2011 ONSC 543 (CanLII), [2011] OJ No 395, online 〈http://canlii.ca/t/hvjqb $\rangle ; R v$ Briscoe, 2012 ABQB 111 (CanLII), [2012] AJ No 196, online: <http://canlii.ca/t/fqc7j>.

${ }^{51} R v W u, 2010$ ABCA 337 (CanLII), [2010] AJ No 1327, online: http://canlii.ca/t/2dfbc>.
} 
with counsel of choice entails, ${ }^{52}$ as well as underlining the limitations of the confessions rule. ${ }^{53}$

\section{Police Interrogation}

Furthermore, case law has underlined how the psychological interrogation methods of the Reid Technique, a method of police questioning used by some police in Canada, ${ }^{54}$ can also function to erode the right to silence and produce confession evidence that may be later deemed inadmissible by the courts. It has been found, in fact to also produce false confessions. ${ }^{55}$ The Reid Technique involves a detailed analysis of the facts of the case, as well as interviewing and interrogation of suspects. The psychological methods that form an essential part of it are confrontational, manipulative and suggestive; it has been referred to as "guilt-presumptive." 56 Custodial interrogation in and of itself is inherently coercive ${ }^{57}$ and at the same time it has been well established that particular police psychological interrogation methods such as the Reid Technique have been known to produce false confessions. In fact, recent court rulings have indicated that the Reid Technique may be thus construed as an attempt to essentially override a suspect's right to silence. As Moore contends:

...the social chemistry of the interrogation room is psychologically disconcerting from the outset. The suspect is informed that he need not say anything. If he opts to remain silent, the same agent who moments earlier informed him that he could remain silent proceeds to ask a litany of questions, and the questions persist, no matter how often the right to silence is invoked. On balance it does not appear to be providing much of a safeguard. ${ }^{58}$

Justice Stromberg-Stein asks in $R v$ Rhodes, "When does no mean no? How many times must a suspect say no? Can a suspect simply be ignored until his or her will is broken down or over-ridden?" ${ }^{59}$ Clearly, the repeated questioning of a suspect may serve to overcome his resolve, disorient and denigrate him, and at times ultimately invoke a confession simply to end the interrogation. It has been argued that "... persistent questioning, especially when coupled with the use of the Reid Technique, should lead to a finding that the statement was not made voluntarily." 60 In $R v$ Chapple, ${ }^{61}$ the accused

${ }^{52} R v$ Smith, 2011 BCSC 1695 (CanLII), [2011] BCJ No 2381, online: 〈http://canlii.ca/t/fp9d2>; $R v$ Chung, 2011 BCCA 131 (CanLII), [2011] BCJ No 446, online: 〈http://canlii.ca/t/fkl27〉.

${ }^{53} R v$ Leslie Somogyi, 2010 ONSC 5585 (CanLII), [2010] OJ No 4350, online: 〈http://canlii.ca/t/2cxr9>; $R$ v Davis, 2011 ONSC 5564 (CanLII), [2011] OJ No 5289, online: 〈http://canlii.ca/t/fp11k〉.

${ }^{54}$ Due in part to these very criticisms the Reid Technique is being used less and less by Canadian police forces, including the RCMP, when questioning suspects.

${ }_{55}^{55}$ Saul Kassin, "The Psychology of Confession Evidence" (1997) 52 Am Psych 221.

${ }^{56}$ Timothy Moore \& C Lindsay Fitzsimmons, "Justice imperilled: False confessions and the Reid Technique" (2011) 57(4) Crim LQ 509-542.

${ }^{57}$ Miranda $v$ Arizona, [1966] 384 US 436 at 458.

${ }^{58}$ Timothy Moore, "The right to silence offers the only real protection during interrogations' (2008) 29:1

Ontario Criminal Lawyers' Association Newsletter at 17.

${ }^{59} R v$ Rhodes, 2002 BCSC 667 (CanLII), [2002] BCJ No 1113, online: 〈http://canlii.ca/t/1czr7> at para 110.

${ }^{60}$ Singh, supra note 21 at 18.

${ }^{61} R v$ Chapple, 2012 ABPC 229 (CanLII), [2012] AJ No 881, online: 〈http://canlii.ca/t/fsh9c $>$. 
asserted her right to silence 24 times, yet it was ignored and a confession secured. In that case, Judge Dinkel, of the Provincial Court of Alberta reiterated Judge Ketchum's earlier denunciation of the Reid Technique from 12 years previous and found that "its use can lead to overwhelmingly oppressive situations that can render false confessions and cause innocent people to be wrongfully imprisoned... innocence is not an option with the Reid Technique." ${ }^{2}$ In this case the subsequent confession was said to have been the product of oppression, where the suspect's will had been overborne, and it was therefore excluded as evidence.

In $R v$ Fitzgerald, ${ }^{63}$ an accused person stated 137 times that she wanted to remain silent when being questioned by the police. The court later found that the "right to silence was rendered meaningless" ${ }^{64}$ and her statement subsequently rejected. In $R v$ Koivisto, ${ }^{65}$ the accused asserted his right to silence 28 times nonetheless the interrogating officer ignored these requests. In $R v$ Mentuck, ${ }^{66}$ police continued to question the accused in spite of the fact that he asserted his right to silence 75 times. ${ }^{67}$ What these cases illustrate is that "persistent questioning" clearly occurs and it is difficult to ascertain not only to what extent these admissions occur because a suspect's right to silence has been overridden, or to what extent they represent the truth. Irrespective of the truth of their contents more often than not confessions obtained through this questionable technique are being admitted in Canadian courts.

In the Canadian context, the connection between the confessions rule, the right to silence and the right to counsel is simple. ${ }^{68}$ The protections afforded by the right to counsel and the right to silence effectively prevent a suspect confessing during a police interrogation, especially to something they did not do - which is clearly linked to a number of wrongful convictions. Denial of those rights, in turn, could lead to the manipulation of an unsuspecting suspect on the part of the police, as well as opening the door to charge, conviction and sentence, all based on what is said during an interrogation. Once a suspect confesses to a crime, whether truthfully or falsely, it is very difficult to retract that confession. The confessions rule has been described as a "safety net" 69 as having counsel present to advise on remaining silent - which would include advising against confessions is essential. A defendant is under no obligation to help police to make the case against him or her.

\footnotetext{
62 Ibid at 122.

${ }^{63} R$ v Fitzgerald, 2009 BCSC 1599 (CanLII), [2009] BCJ No 2333, online: 〈http://canlii.ca/t/26smh >.

${ }^{64}$ Ibid at 28.

${ }^{65} R v$ Koivisto, 2011 ONCJ 307 (CanLII), [2011] OJ No 2794, online: 〈http://canlii.ca/t/flxn2〉.

${ }^{66} R v$ Mentuk, 2000 MBQB 155 (CanLII), [2000] MJ No 447, online: 〈http://canlii.ca/t/4vs3>.

${ }^{67}$ Kirk Makin, "Gag order obscures man's innocence” The Province, (23 Oct 2009), online: https:/www.theglobeandmail.com/news/national/gag-order-obscures-mans-innocence/article25576991/. ${ }^{68}$ The cases discussed in this section (Oickle, Singh \& Sinclair) have been referred to as the "interrogation trilogy" as they all raise questions about the lengths the police are allowed to go when attempting to obtain a confession from a suspect (Sinclair, supra note 36 at 77; Weitzman \& Campbell, supra note 23 at 10).

${ }^{69}$ Doyle \& Hatcher, supra note 49.
} 


\section{Scotland}

As in most common law jurisdictions, in Scotland the right to remain silent during police questioning is of great importance and is derived from the fundamental basis of a criminal justice system where an accused person is presumed innocent until proven guilty. ${ }^{70}$ While the right to silence has long been afforded Scottish suspects, it was only until quite recently that the right to counsel was similarly provided. The effect of this was clearly problematic as an important rationale for the right to legal representation is that it can be of assistance in understanding and enforcing the right to silence. ${ }^{71}$ Prior to the decision in Cadder v HM Advocate ${ }^{72}$ (to be discussed infra) and recent legislative changes in 2010 and 2016, this situation seemed out of step with other developed nations and particularly other members of the Council of Europe. For the unrepresented suspect, it may prove too easy to answer questions of a persuasive and intimidating police officer in the confines of the rather hostile environment of a police station. While access to legal assistance may not necessarily protect against self-incrimination in all cases, the presence of a lawyer will allow a detainee to better exercise his or her rights and relieve pressures that may serve to induce a false confession. ${ }^{73}$

Prior to recent changes, the provisions to detain and question suspects were found in sections 14 and 15 of the Criminal Procedure (Scotland) Act, 1995. ${ }^{74}$ These provisions permitted police, where there were reasonable grounds for suspecting that a person has committed or is committing an offence punishable by imprisonment, to detain and question suspects for up to six hours, without access to legal assistance. This may be in part due to the fact that the right to silence was not considered necessary, as arrest per se was viewed as being for "arrest on charge". ${ }^{75}$ While the Act allowed that a solicitor could be informed that a particular suspect was detained and questioned (subsection 15 (1) (b)), the suspect had no right of consultation with that or another solicitor. At the same time, the police officer was required to inform the person "... of his suspicion, of the nature of the offence which he suspects has been or is being committed and of the reason for the detention..." (subsection 14 (6)). Moreover, the detainee could be released prior to the six-hour timeline if the person was arrested, if detained pursuant to another matter or if the grounds for detainment no longer existed (subsection 14 (2) (a-c).

The sections 14 and 15 power to detain and question suspects originated from the Thomson Commission, established in 1975, that examined the law regarding pre-trial and

\footnotetext{
70 The Carloway Review: Report and Recommendations, (17 Nov 2011), online: http://www.gov.scot/resource/Doc/925/0122808.pdf. [Carloway].

${ }^{71}$ Fiona Leverick “The right to legal assistance during detention' (2011) 15:3 Edin LR 352 at 361 [Leverick].

72 Cadder v HM Advocate [2010] UKSC 43, 2010 SLT 1125, online: http://www.bailii.org/uk/cases/UKSC/2010/43.html [Cadder].

${ }^{73}$ Lewis Kennedy, "Legal advice at police stations" (no date) online: http://www.mackinnonadvocates.co.uk/articles-cases/legal-advice-at-police-stations.aspx.

${ }^{74}$ Criminal Procedure (Scotland) Act, 1995, online: http://www.bailii.org/uk/legis/num_act/1995/ukpga_19950046_en_1.html at s 15 (1) (b).

${ }^{75}$ Clive Walker, 'Post-charge questioning in UK terrorism cases: Straining the adversarial process' (2016) 20:5 Int'1 J HR 649.
} 
trial procedures in Scotland. The rationale for this short period of custody in detention (or rather arrest on suspicion) for six hours was to allow for the questioning of a suspect with a view to helping the police further their investigation. ${ }^{76}$ The Thomson Commission had established that the purpose of detention may be "defeated by the participation of his solicitor" and allowed that it was a matter of police discretion whether a detainee could be interviewed by his solicitor; this right was affirmed however for an arrestee. ${ }^{77}$ As Leverick points out, no adverse inferences could be drawn from silence during the interview but any answers provided by the suspect to police questioning could be used in evidence so long as the procedure was fair. ${ }^{78}$ As per subsection 17 (2) of the Criminal Procedure (Scotland) Act, $1995,{ }^{79}$ it was only after being arrested and charged that a suspect had full right and access to consultation with counsel. While it is difficult to ascertain the impact that this socalled right to silence had on detainees, without the concomitant right to counsel, and the nature of what may have been revealed during police interviews, the recent common law and statutory changes that establish this right have significantly increased the protections of accused persons.

Other statutory provisions regarding the right to silence for detainees in Scotland are found in the European Convention on Human Rights, ${ }^{80}$ (ECHR) with its advisory capacity over Scottish law and procedure. While the Convention itself does not expressly provide for the right to silence and the right against self-incrimination, it has been implied by the European Court as lying "at the heart of the notion of a fair procedure under article 6." ${ }^{81}$ As discussed, the right to silence is subsumed under the right to a fair trial subsection $6(1)$ :

1. In the determination of his civil rights and obligations or of any criminal charge against him, everyone is entitled to a fair and public hearing within a reasonable time by an independent and impartial tribunal established by law.

While the law regarding at what point access to counsel is guaranteed by subsection 6 (1) is not clear, it was left up to individual signatory countries to establish those parameters. The provisions of article 6 (1) on their face appear inconsistent with the lack of consultation with counsel for those first six hours of questioning for suspects/detainees under section 14 of the Criminal Procedure (Scotland) Act, 1995. In recent years, however, through a series of court decisions the parameters of this right became evident as it applied to Scottish suspects. While Cadder expressed the state of law in Scotland on these issues at

\footnotetext{
${ }^{76}$ Carloway, supra note 70, at s 5.0.1.

77 Thomson Commission, Criminal Procedure in Scotland, (October, 1975) at para 7.16., online: http://www.gov.scot/Resource/Doc/925/0110006.pdf.

${ }^{78}$ Leverick, supra note 71 at 356.

${ }^{79}$ Criminal Procedure (Scotland) Act, 1995, c-46, online: http://www.bailii.org/uk/legis/num_act/1995/ukpga_19950046_en_1.html.

80 The ECHR has an advisory capacity over Scottish law and procedure and was brought into national law by the Scotland Act, 1998 and the Human Rights Act, 1998.

${ }^{81}$ From Saunders v United Kingdom (1996) 23 EHRR 313, [1996] ECHR 65, online: http://www.bailii.org/eu/cases/ECHR/1996/65.html found in Carolway, supra note 70 at s 7.09. In this case, the problem was an offence of silence, rather than a right to silence.
} 
that time, it was a response to an appeal in HMv McLean ${ }^{82}$ and also an affirmation of the ECHR decision in Salduz $v$ Turkey that clarified its perimeters ${ }^{83}$ For those reasons the cases will be discussed as they occurred chronologically.

\section{A. Case Law}

\section{a. Salduz v Turkey [2008] - Right to Counsel on Detention (Europe)}

The decision by the European Court of Human Rights (ECtHR) sitting as a Grand Chamber in the case of Salduz found that suspects should have access to a lawyer from their first interrogation, unless there were compelling reasons not to grant access. Yusuf Salduz, a Turkish national, was charged with aiding and abetting a terrorist organization by participating in an unlawful demonstration and hanging an illegal banner from a bridge. ${ }^{84}$ Salduz was interrogated by police officers without access to a lawyer, although he was reminded of the charges against him and the right to remain silent; he made a number of admissions during the interview that were used in evidence against him. ${ }^{85}$ Salduz later retracted the statements and claimed they had been made under duress. Doctors examined Salduz on two occasions shortly following his arrest (at 12:30 on 30 May 2001), approximately 14 hours after his arrest and again at 23:45 on 1 Jun $2001{ }^{86}$ While the medical reports found no trace of ill treatment on his body on both occasions, the fact that he was examined at all and that Salduz claimed the statements were made under duress, raises questions as to how the statements were extracted from him. Salduz's appeal of his conviction, based on a breach of articles 5 (right to liberty and security) and 6 of the Convention was dismissed by the Ninth Chamber of the Court of Cassation in June 2002. Heard by the ECtHR in November 2008, the Court found that: "....in order for the right to a fair trial to remain sufficiently 'practical and effective' ... article 6 (1) requires that, as a rule, access to a lawyer should be provided as from the first interrogation of a suspect". ${ }^{87}$ Further, even though Salduz had the opportunity to challenge the evidence used against him at trial and on appeal "the absence of a lawyer while he was in police custody irretrievably affected his defense rights". ${ }^{8}$ Moreover, the right to a lawyer was recognized as beginning not with trial, but as soon as the suspect is in custody and being questioned, from the first interrogation - which is a much wider application of that right than had been previously envisaged.

\section{b. HMA v McLean [(2009] - No Right to Counsel on Detention (Scotland)}

In this case, Duncan McLean was 19 years old when detained for questioning under section 14 of the Criminal Procedure (Scotland) Act, 1995 regarding a motor vehicle theft

\footnotetext{
${ }^{82}$ HM v McLean, [2009] HCJAC 97, 2010 SLT 73, online: http://www.bailii.org/scot/cases/ScotHC/2009/2009HCJAC97.html [McLean].

${ }^{83}$ Salduz v Turkey [2008] ECHR 1542, (2009) 49 EHRR 19, online: http://www.bailii.org/eu/cases/ECHR/2008/1542.html [Salduz].

${ }^{84}$ Ibid at 12.

${ }^{85} \mathrm{Ibid}$ at 14

${ }^{86}$ Ibid at 13, 16.

${ }^{87}$ Ibid at 55.

${ }^{88}$ Ibid at 62 .
} 
and arson; he did not have, nor was he offered, legal advice or legal representation while interviewed. ${ }^{89}$ During the police interview McLean made a number of admissions that the Crown intended to rely on at trial. When served with an indictment, McLean lodged a devolution minute ${ }^{90}$ that leading such evidence in the absence of legal advice or presence of a lawyer during the interview was "...contrary to his rights conferred by Article 6 (3) (c) of the European Convention on Human Rights". ${ }^{91}$ The Court found that the ECtHR ruling was not binding in Scottish courts and that sufficient safeguards existed in Scottish law and rules of evidence and procedure to protect detainees, as coerced confession evidence could be rendered inadmissible, an adverse inference from silence could not be drawn and any admissions made during an interview must be corroborated. In rejecting Salduz, the Scottish judges ruled that such questions require a consideration of all of the circumstances of the case and that the lack of legal representation during detention was not a violation of art. 6 given that the availability of the other safeguards was considered sufficient to guarantee a fair trial. ${ }^{92}$

\section{c. Cadder v HM Advocate [2010] - Right to Counsel on Detention (Scotland)}

The UK Supreme Court ruling in Cadder included an appeal against the decision in McLean. The link between the two cases was the fact both defendants had been detained under section 14 and each case gave rise to "the question whether the Crown's reliance on admissions made by a detainee during his detention while being interviewed by the police without access to legal advice before the interview begins is incompatible with his right to a fair trial". ${ }^{93}$ Peter Cadder was detained and interviewed by the police in May 2007 based on suspicion of his involvement in a serious assault. After being cautioned twice, Cadder was interviewed by the police and declined to have a solicitor contacted on his behalf; during the interview Cadder made a number of admissions regarding the assaults that became the basis under which he was charged and ultimately convicted in May 2009 of two assaults and a breach of peace..$^{94}$ In July 2009, Cadder lodged his appeal based in part on the procurator fiscal deputy's ${ }^{95}$ reliance on the contents of his interview which constituted a breach of the art. 6(1) right to a fair trial of the ECHR, as a solicitor was not present during

\footnotetext{
${ }^{89}$ Mclean, supra note 82 at 1.

${ }^{90}$ A "devolution minute" refers to the requirement in proceedings on indictment that written notice to raise a devolution issue must be given to the clerk of the court within certain time frames. Devolution refers to the process of transferring power from the central government to the regions and nations of the UK; one policy area that has devolved for Scotland is justice and policing, online:

https://www.deliveringforscotland.gov.uk/scotland-in-the-uk/devolution/.

${ }^{91}$ McLean, supra note 82 at 2.

92 SPICe Briefing, (2011). Criminal Procedure: Responses to Cadder v HM Advocate, online: http://www.scottish.parliament.uk/ResearchBriefingsAndFactsheets/S3/SB 11-20.pdf.

${ }_{93}$ Cadder, supra note 72 at 1.

${ }^{94}$ Ibid at 5.

95 The role of this individual, similar to a Canadian prosecuting or Crown Attorney, involves taking decisions on criminal proceedings, conducting court and working closely with the police and other criminal justice partners, online: https://www.copfs.gov.uk/careers/job-profiles/legal-roles.
} 
the interview. ${ }^{96}$ At first sift stage ${ }^{97}$ Cadder's appeal to the High Court was refused, based on the ruling in McLean; he later sought leave to appeal to the UK Supreme Court. After hearing the case in 2010, the Court ruled that in fact Scottish law and procedure for detention without access to legal representation was inconsistent with article 6 (1) of the ECHR; ultimately, Cadder's right to a fair trial had been breached. Additionally, the Court overruled the unanimous decision in McLean and found that the guarantees available under the Scottish system were not sufficient to secure a fair trial. The unanimous ruling in Cadder "set in motion a chain of events that could have extraordinarily wide implications for the Scottish criminal justice system". ${ }^{98}$ Scottish courts needed to rectify the procedural gap that this ruling established; therefore detainees now have the right to legal advice and assistance prior to and during police interview.

\section{d. Legislative change}

Even before the release of the decision in Cadder, the Scottish government issued guidelines for police regarding detainee access to solicitors. The guidelines permitted the police to offer the detainee the possibility of consultation with a solicitor in person or by telephone. This was done in an attempt to protect prosecutions pending the Court's decision. ${ }^{99}$ And shortly after the Cadder ruling the Criminal Procedure (Legal Assistance, Detention and Appeals) (Scotland) Act, $2010{ }^{100}$ came into force, under emergency legislation procedures, which provided a statutory right to legal advice for suspects being questioned by the police (subsection 15A) and extended the six-hour period during which a suspect can be detained for questioning by the police to twelve hours (subsection 14 (A) (2)). The twelve-hour detention period could also be extended to twenty-four hours (section 14A) in those cases where it was deemed necessary "(a) to secure, obtain or preserve evidence (whether by questioning the person or otherwise) relating to an offence in connection with which the person is being detained, (b) an offence in connection with which the detained person is being detained is one that is an indictable offence, and (c) the investigation is being conducted diligently and expeditiously." Moreover, this period was substantially less than the provisions already in place in England and Wales through the Police and Criminal Evidence Act, 1984, where police are permitted to hold a suspect for

\footnotetext{
96 The other grounds related to the sheriff's directions in relation to breach of peace and the reliance of the prosecutor on dock identification evidence (Cadder, supra note 72 at 8).

${ }^{97}$ Criminal appeals in Scotland proceed when "a senior judge or appeal sheriff decides whether or not to grant permission for an appeal to proceed. This is called the sift process. There can be two parts to this. A single judge or appeal sheriff will consider whether there are 'arguable grounds' for an appeal to proceed based on legal matters and evidence. Where permission to appeal is refused at the first sift, an appeal can be made against that refusal to a second sift. This will be considered by two or three judges/sheriffs, depending on the type of appeal." Online at: https://www.scotcourts.gov.uk/the-courts/supreme-courts/high-court/criminalappeals.

98 James Chalmers \& Fiona Leverick, "'Substantial and radical change'; A new dawn for Scottish criminal procedure?” (2012) 75:5 MLR 837 [Chalmers \& Leverick].

${ }_{99}$ Police Services of Scotland, Solicitor Access Guidance Document (20 Mar 2015), online: http://www.scotland.police.uk/assets/pdf/151934/184779/psos_solicitor_access_guidance_document_ver_1. 00.pdf. The guidelines permitted the police to offer the detainee the possibility of consultation with a solicitor in person or by telephone.

${ }^{100}$ Criminal Procedure (Legal Assistance, Detention and Appeals) (Scotland) Act, 2010 asp 15, online: http://www.bailii.org/scot/legis/num_act/2010/asp_201015_en_1.html.
} 
24 hours, extendable to 36 hours on the approval of a senior police officer, with extensions up to 96 hours possible with the approval of a magistrate. ${ }^{101}$

The Act also provided a mechanism that could be used (if necessary) to ensure that adequate legal aid arrangements were available for detained suspects (s 8A) and reinforced the principles of certainty and finality in cases referred to the Scottish Criminal Cases Review Commission (SCCRC) ${ }^{102}$ (section 7) set out in the Supreme Court's decision in Cadder. While the changes allowed for a consultation with a solicitor to take place over the telephone where appropriate, it was not envisaged that anyone charged with a serious offence would rely solely on telephone advice.

Given that the decision in Cadder forced the Scottish government to quickly respond with legislative changes to assure the provision of legal assistance to detainees, an independent review commission chaired by Lord Carloway was mandated shortly thereafter to review the law and practice of questioning suspects in a criminal investigation in Scotland. Its task was to consider the implications of the recent decisions, and inter alia, the requirement for legal advice prior to and during police questioning. As noted by Carloway, the "long-lasting implication of Cadder is that the system must fully embrace and apply a human rights-based approach". ${ }^{103}$ The recommendations stemming from the review were similarly wide ranging and far-reaching, addressed the requirements of the Convention and focused on arrest, detention, custody, investigation, evidence and appeals. Most controversial among them were the abolishment of subsection 14 detention, abolishment of the corroboration requirement in criminal cases and the requirement of the SCCRC to consider finality and certainty as justifications for referring cases to the High Court; many such recommendations were never implemented by the government. Chalmers and Leverick note that Carloway's proposals may have improved procedural safeguards for accused persons, but effectively ignored substantive safeguards, beyond the requirement of proof beyond reasonable doubt ${ }^{104}$ - a limited protection at best. Given that the review's recommendations did not have the force of law, the government was slow to implement them legislatively and ultimately did not fully embrace Carloway's vision for change.

The more recent Criminal Justice (Scotland) Act, 2016, only fully enacted in 2018, introduced sweeping reform to Scottish courts and criminal procedure, stemming in part from Lord Carloway's review, as well as a need to bring procedure more in line with the European Convention on Human Rights and the UK Police and Criminal Evidence Act, 1984. This act has been described as providing a bold affirmation of the protection of the right to silence at the police station. ${ }^{105}$ Regarding the police powers of arrest and interview, sections 14 and 15 of the Criminal Procedure Scotland Act, 1995 were replaced and the concept of detention was abolished in theory, but in practice the law uses the word "arrest" to by that very fact, replace detention. The police are permitted to arrest without warrant

\footnotetext{
${ }^{101}$ Police and Criminal Evidence Act, 1984 c 60 at s 4, online: http://www.bailii.org/uk/legis/num_act/1984/ukpga_19840060_en.html.

102 The SCCRC is a public body that addresses miscarriages of justice including both conviction and sentence; it makes independent investigations and in some cases refers cases directly to the High Court for review.

103 Carloway, supra note 70 at 2.

${ }^{104}$ Chalmers \& Leverick, supra note 98 at 863-864.

105 Robert Shiels, "Scots Criminal Law and the Right to Silence", (2018) 42:2 Dundee Stud LR No 3 at 13.
} 
(subsection 1 (1)); also introduced under section 1 is the provision of arrest more than once for the same offence (subsection 2 (1)). The procedure to initially detain a suspect and then later arrest and charge has also been abolished. At the same time, the law allows, under sections 7-10 to keep a person in custody for 12 hours (and a further 12 hours in more serious matters) without charging them. The Act also introduced the concept of "postcharge questioning" (subsection 35 (1)), which allows for the court to authorize the police to interview a suspect again, following an official accusation of committing an offence. Thus, it would appear that while instituting many of Lord Carloway's provisions, the new law also spread the reach of investigating officers by allowing for an altered form of detention (sections 7-10) and through the possibility of post-charge questioning.

The law allows that a person in police custody has the right to consultation with a solicitor at any time, including consultation on the phone (subsections 44 (1), (4)). Moreover, the accused can have a solicitor present, before being questioned by the police or at any other time during the questioning (section 32; section 44). Outside of the requirement to provide personal details to the police, the statutory right to silence is absolute (subsection 34 (4)). Any statements made by a suspect are only admissible and used in evidence if they are truly spontaneous and voluntary. ${ }^{106}$ The Crown must demonstrate the voluntariness of the statement, taking into account the whole circumstances. ${ }^{107}$ Moreover, under Scots law, a suspect is advised that they are under no obligation to answer any questions (subsection 34 (4), and contrary to English law, no inference can be drawn from silence regarding the credibility of the evidence on matters that the accused declined to say anything about. ${ }^{108}$

\section{e. Further Decisions}

Subsequent to the ruling in Cadder a number of other cases ${ }^{109}$ were decided by the courts that further interpreted the scope of the right to legal assistance during detention emerging from the original decision. In HMA $v P$ (Scotland), ${ }^{110}$ the Court considered whether the principle in Salduz extended to the use of other evidence that was discovered as a result of answers given by the accused while in custody without access to legal advice. On appeal, the accused submitted that his rights under article 6 (3) would be contravened if the Crown used this evidence - obtained as a direct result of his replies to police questioning that occurred absent the benefit of legal assistance. The evidence was ultimately found to be acceptable as there is "no absolute rule that the fruits of questioning of an accused without access to a lawyer must always be held to be a violation of his rights under Articles 6 (1) and 3 (c)". ${ }^{111}$ Other issues arising in relation to the aftermath of Cadder were based on when and at what point access to legal assistance should be provided and whether the rule established in Salduz applies to questioning that occurs prior to being taken into

\footnotetext{
106 HM Advocate v Mair 1982 SLT 471.

${ }^{107}$ HM Advocate v Hawkins, (2018) SCCR 1, [2017] HCJ 79, online: http://www.bailii.org/scot/cases/ScotHC/2017/[2017]_HCJ 79.html.

${ }_{108}$ Larkin v HM Advocate 2005 SLT 1087, [2005] HCJAC 28.

109 These decisions have been referred to as "Sons of Cadder" as they followed from the original decision.

${ }^{110}$ HMA v P (Scotland), [2011] UKSC 44, 2011 SCCR 712, online: http://www.bailii.org/uk/cases/UKSC/2011/44.html [HMA $v$ P].

${ }^{111}$ Ibid at 27.
} 
custody. In three simultaneous cases referred by the Appeal Court of the High Court of Justiciary to the UK Supreme Court the question was whether the use of statements made outside the police station by the accused were in violation of the appellant's rights to a fair trial under articles 6 (1) and 6 (3) (c) of the ECHR. The Court found in those cases was that statements made prior to being "in custody" were admissible, but when incriminating statements were made while handcuffed, this was considered custody regardless of where it happened, and such statements were inadmissible. ${ }^{112}$ While admittedly the Court has recognized a wider scope to the right to legal assistance, as these cases illustrate it still limits the situations where that is applicable.

At the same time, the law recognized that defendants have the right to waive legal assistance and required that a waiver must be "voluntary and unequivocal and in full knowledge of its consequences." 113 In cases where the issues under consideration had to do with waivers, the Scottish courts have ruled that not only is there no absolute rule to legal advice regarding waiving that legal advice but also neither is legal advice necessary for waiving the right to legal advice. ${ }^{114}$ Currently there is no requirement to establish whether or not an accused person, in waiving the right to counsel, understands what that means and if is an informed and voluntary decision. Since Cadder, these decisions by the Court reflect a narrowing of recognized rights by allowing for the "fruits of questioning" to be used in some cases, and furthermore by not requiring a justification for waiving a right to counsel.

\section{Discussion and Conclusions}

In Canada the right to silence appears to be inextricably linked to the right to counsel, or the right to legal assistance as it is commonly referred to in Scotland. The right to silence is considered fundamental in many jurisdictions, and in Scotland it is an unqualified right and while not absolute ${ }^{115}$ it is not fettered by the adverse inferences that may be drawn in England and Wales. ${ }^{116}$ Leverick discusses four possible justifications for the right to legal assistance and protecting the right to silence is just one of them. They are: 1. Provision of emotional support, 2. Protection from ill treatment, 3. Assistance in understanding or enforcing the right to silence, and 4. Preventing wrongful convictions. ${ }^{117}$ While Leverick rejects the first and second as unnecessary for protecting the right to silence as they can be achieved through other means such as through videorecording of interviews, she recognizes that the third justification is the most complex. The right to counsel facilitates the right to silence in three ways - by ensuring suspects understand the right to

\footnotetext{
${ }^{112}$ Ambrose v Harris [2011] UKSC 43 [Ambrose], 2011 SCCR 651; HM Advocate v M. [2011] UKSC 43, 2011 SCCR 651; HM Advocate v G. [2011] UKSC 43 online: http://www.bailii.org/uk/cases/UKSC/2011/43.html. [Ambrose].

${ }_{113}$ Pishchalnikov v Russia, [2009] ECHR 1357, online: http://www.bailii.org/eu/cases/ECHR/2009/1357.html at 77.

${ }^{114}$ Birnie v HM Advocate [2011] UKSC 54 at 28; McGowan v B [2011] UKSC 54, 2012 SCCR 109, online: http://www.bailii.org/uk/cases/UKSC/2011/54.html.

${ }^{115}$ Further, the ECtHR in John Murray v United Kingdom, [1996] ECHR 3, (1996) 22 EHRR 29, online: http://www.bailii.org/eu/cases/ECHR/1996/3.html at 655 has held that the privilege against self-incrimination was not absolute and in that case the concern was over drawing of inferences in the absence of legal advice.

116 Police and Criminal Evidence Act, Code C, 2014.

${ }^{117}$ Leverick, supra note 71 at 362-375.
} 
silence (3a), by assisting them in identifying their best interests (3b) and by assisting them in enforcing their choices (3c). ${ }^{118}$ While Leverick further argues that if the right to counsel is premised on $3 \mathrm{a}$ and $3 \mathrm{~b}$ it does not require the physical presence of the solicitor nor does is require assistance during the interview; those latter conditions are only necessary for $3 \mathrm{c}$.

Leverick's position appears unsustainable as it fails to accept that the police interview, in and of itself, is a coercive experience and only those suspects with a particularly strong constitution may be able to effectively withstand the effects of forceful and insistent police questioning. In Scotland, the time limitations first imposed by section 14 of the Criminal Procedure (Scotland) Act, 1995 and now sections 7-10 of the Criminal Justice (Scotland) Act, 2016 of 12 hours will likely serve to restrict the length of such questioning, irrespective of its intensity. At the same time, the power to re-arrest someone on the same offence, as permitted by subsection 2 (1), may increase the opportunities for questioning by the police, and the 12-hour limit is effectively reduced on each successive interview. In Canada, however, given that the right to counsel in reality involves a "onetime" consultation, with re-consultation only on material change in the accused's situation, the right to counsel appears to be a necessary condition in ascertaining that the right to silence is respected.

Given these limits on the ability to consult with counsel, safeguarding the right to silence is of particular importance. The presence of a competent solicitor in such an environment, whether for a brief or extended period, could go a long way towards ensuring that the right to silence is respected, even in the face of powerful police questioning. Similarly, the simple physical presence of a solicitor may serve to fetter police actions, in immeasurable ways. Leverick also argues that her fourth justification for recognizing the instrumental value of the right to legal assistance, preventing wrongful convictions, is harder to justify. She believes that it is not always obvious how a solicitor could be effective in this way, save for preventing some types of coerced false confessions. ${ }^{119}$ This appears to understate the value of effective counsel in not only preventing such confessions from occurring at all by assisting the suspect in invoking the right to silence, but also in making the case for preventing the suspect from contributing to the prosecution's case in other ways. Moreover, there are particular principled reasons for recognizing an absolute right to silence, reasons that overlap with Leverick's contentions. Roberts and Zuckerman believe the following three reasons justify recognizing an absolute right to silence: intrinsic rationales - such as protection of privacy and prevention of cruel choices; conceptualist rationales - such as the adversary procedure and the presumption of innocence; and instrumental rationales - prevention of wrongful conviction. ${ }^{120}$ These considerations raise the important point that justifications regarding the application of this right serve multiple purposes and depending on the perspective, some are more convincing and significant than others.

It could be argued that the right to silence becomes watered down when not accompanied by a concomitant right to counsel. Most suspects in criminal investigations

\footnotetext{
118 Ibid at 376.

${ }^{119}$ Ibid at 376.

${ }^{120}$ Paul Roberts and Adrian Zuckerman, Criminal Evidence (Oxford: Oxford University Press: 2010) at 549.
} 
lack the sophistication and legal wherewithal to understand they are not obligated to answer police questions. Moreover, increasingly sophisticated forms and types of police interrogation methods (such as the Reid Technique, used in the past in North America and discussed earlier) can serve to induce false admissions and false confessions. In March 2015, the Law Society of Scotland issued a document entitled "Police Station Interviews: Advice and Information from the Law Society of Scotland" ${ }^{121}$ where it outlined the role and obligations of a solicitor in this context, which is "to represent, protect and advance the legal interest and rights of the suspect". It also posits that a solicitor may intervene when the suspect is interrupted or when questions are considered improper, hypothetical, lies, leading, ambiguous, oppressive, threatening or when they imply inducements. The solicitor may also intervene when there is any attempt to put on record prejudicial or misleading observations and should be alert to the tone of the interview and intervene if it becomes oppressive. ${ }^{122}$ While this may be a laudable attempt to address forms of obvious police misconduct in Scotland, in Canada the often psychologically-based police interrogation techniques routinely used have been permitted by courts and been described as forms of "other police trickery" in police questioning that fail to "shock the community."

This article has attempted to lay the groundwork for the argument that changes in one area in criminal law and criminal procedure are often accompanied by concomitant and contrary changes in other areas. In Canada, the introduction of the Charter heralded a new era of recognition of individual rights; legal rights enshrined in sections 7-14 provided for protections from overzealous policing through the recognition of, inter alia, rights to silence, to counsel, against unreasonable search and seizure and to the presumption of innocence. The right to silence, subsumed under section 7 rights to life, liberty and security of the person, is recognized as being closely linked to the right to counsel (subsection 10 (b)) and a number of Supreme Court decisions illustrate how the courts have interpreted the scope of those rights. While the Court in Hebert first recognized the right to silence, the decisions in Singh and Sinclair served to substantially curb the parameters of that right by allowing for a single, initial consultation with a lawyer, followed by a second consultation only when there was a material change in circumstance. Case law has illustrated that in some cases dozens of invocations of the right to silence have little effect on police questioning, which has resulted at times in admissions being made that may later prove false; it would appear that in some instances the courts are willing to let the "police do their job". It could thus be argued that in Canada the pendulum has swung once again, this time away from enshrined rights and protections against the overwhelming power of the state and moved towards fewer impediments on law enforcement, allowing suspects to be

${ }^{121}$ The Law Society of Scotland, 'Police Station Interview: Advice and Information from the Law Society of Scotland', online: https://www.lawscot.org.uk/media/8819/police-station-advice-and-information-march2015-section-f-division-advice.pdf.

${ }^{122}$ Accordingly oppression may result from “... continued repetition of questions which have already been answered or to which a 'no comment' answer has been given, from an officer raising his/her voice or becoming angry or from continued interruptions of the suspect by the officer", (at 6(B)) The Police Interview (A) The Solicitor's Role during the Police Interview, online: https://www.lawscot.org.uk/media/8819/policestation-advice-and-information-march-2015-section-f-division-advice.pdf. In the Canadian context this type of questioning occurs routinely and given that a solicitor/lawyer is not permitted to be present for the entire interview, it can go unchecked.

${ }^{123}$ Oickle, supra note 22 at $65,91$. 
questioned with qualified impunity. The ramifications of this for the possibility of false admissions resulting in wrongful convictions are great.

In Scotland, to a degree, the opposite effect seems to have occurred. The provisions under sections 14 and 15 of the Criminal Procedure (Scotland) Act, 1995 allowed police to question suspects without the right to consult a solicitor for up to six hours, although a solicitor could be informed that a suspect was in custody. Following the ECtHR decision in Salduz in 2008 this could no longer stand; denying a suspect in custody the right to consult with a lawyer was contrary to the right to a fair trial under art 6 (1) and 6 (3) (c) of the ECHR. The Appeal Court appeared to reject this contention in McLean in 2009, however the UK Supreme Court's decision in Cadder in 2010 represented a sea change in Scottish criminal procedure. The decision in Cadder and the subsequent legislative changes through the Criminal Procedure (Legal Assistance, Detention and Appeals) (Scotland) Act, 2010 (section 15A) and the Criminal Justice (Scotland) Act, 2016 (section 32) provided for a statutory right to legal advice for suspects when questioned by the police. This right begins with initial questioning and extends throughout the interview - an unqualified right as no adverse inference can be drawn from the exercise of the right to silence. In the aftermath of Cadder and the legislative change that followed, the independent review commission called by the Scottish government and chaired by Lord Carloway, further refined aspects of criminal law and procedure affecting that right. Moreover, a number of cases have been decided in the courts post-Cadder that illustrate the scope of that decision and it appears that the protections of a right to fair trial under articles 6 (1) and 6 (3) (c) do not always extend to the leading of evidence that is produced by the initial problematic questioning (see e.g. $H M A v P$ ). ${ }^{124}$ Other case law demonstrates that the moment of "charge" that engenders these protections will vary and that the courts are reticent to extend the fair trial protections too far (see e.g. Ambrose). ${ }^{125}$ It could thus be argued that in Scotland the pendulum swing towards greater rights protections began with the decision in Cadder and subsequent legislative change However, cases post-Cadder, and sections of the Criminal Justice (Scotland) Act, 2016 represent a narrowing of the application of these rights which may reflect a further pendulum swing back towards more powers for law enforcement in response to greater protections for suspects while detained and questioned. It would seem that currently, the right to a lawyer is more important normatively and more effective practically, than the right to silence. ${ }^{126}$

The implications for wrongful convictions of the right to silence, and concomitant right to counsel, are self-evident. People who falsely confess to crimes that they have not committed often end up convicted and sentenced for things they did not do. In fact, estimates from the New York-based Innocence Project indicate that in 29 percent of the over 375 DNA exonerations to date, the accused person made a false confession or false admission. ${ }^{127}$ While it is not known whether the individuals who falsely confessed did so absent legal representation or without advice regarding their right to remain silent, common

124 HMA v P, supra note 110.

${ }^{125}$ Ambrose, supra note 112.

${ }^{126}$ Clive Walker, personal communication, 16 Jul 2016.

${ }^{127}$ Innocence Project, "DNA Exonerations in the United States" online:

https://www.innocenceproject.org/dna-exonerations-in-the-united-states/ 
sense would dictate the obvious. Police interrogations can be intimidating experiences, people are given mixed messages (in some cases informed of their right to remain silent and then immediately followed by hours of questions), and police can and do lie to suspects about evidence, about co-accused persons and about the implications of a confession ("Just tell us what you did and you can go home"). Consequently, the right to silence and the right to counsel can be eroded by police in their zeal to obtain a confession and ultimately a conviction, whether rightfully or wrongfully. In such situations, having accompanying legal representation throughout the process, could act to safeguard against such errors. In Scotland, the historically absent legal protections in this regard have now been reversed, in Canada, Charter protections of these rights have been increasingly eroded in favour of greater power granted to law enforcement. This comparative analysis has revealed that regardless of the different directions that case law and statute have taken in both Canada and Scotland, vigilance is required to hold state actors (police and prosecutors) accountable for respecting the rights of accused persons. To do otherwise runs the risk of further convictions in error and the accompanying suffering that invariably accompanies them. 